\title{
Propagation of Drosera rotundifolia and Drosera capensis in an in vitro Culture System
}

\author{
Ileana MICLEA ${ }^{1 *}$, Marius ZĂHAN ${ }^{1}$ \\ ${ }^{1}$ Department of Animal Reproduction, University of Agricultural Sciences and Veterinary Medicine, 3-5, \\ Mănăştur Street, 400372, Cluj-Napoca, Romania. \\ *Corresponding author, e-mail: ileana.miclea@usamvcluj.ro
}

Bulletin UASVM Animal Science and Biotechnologies 74(2)/ 2017

Print ISSN 1843-5262; Electronic ISSN 1843-536X

DOI:10.15835/buasvmcn-asb: 0018

\begin{abstract}
Drosera rotundifolia and Drosera capensis (Droseraceae) are carnivorous plants grown as ornamentals and sources for homeopathic medicine. The aim of this study was to optimize nutrient and growth regulator concentrations for the in vitro propagation of these species. Half strength MS medium $(1 / 2 \mathrm{MS})$ was supplemented with kinetin $(0.5,2,5 \mathrm{mg} / \mathrm{l})$ or 6-benzyladenine $(3,5 \mathrm{mg} / \mathrm{l})$ and plantlets were transferred to $1 / 2 \mathrm{MS}$ with or without cytokinins. After 8 weeks rosette diameter, plant height, number of roots, root length were recorded and plants were cultured in full strength MS, $1 / 2 \mathrm{MS}$ or $1 / 2 \mathrm{MS}$ with $0.5 \mathrm{mg} / \mathrm{l} \alpha$-naphthaleneacetic acid for the same period of time. Afterwards, plant characteristics (number of roots, root length, number of shoots, number of flower stalks) were assessed. For $D$. rotundifolia, shoot development and rosette diameter increased significantly in the medium with $0.5 \mathrm{mg} / \mathrm{l} \mathrm{kinetin}$ and $3 \mathrm{mg} / \mathrm{l}$ 6-benzyladenine, while root development decreased. Plant growth regulator free medium was more suitable for root development than medium with $\alpha$-naphthaleneacetic acid and thus supported the formation of significantly more flower stalks. For D. capensis, kinetin was detrimental for shoot development, the optimum medium for both shoot and root formation being MS without plant growth regulators.
\end{abstract}

Keywords: auxins, cytokinins, Drosera rotundifolia, Drosera capensis, in vitro

\section{INTRODUCTION}

The genus Drosera (sundews) is a large group of carnivorous plants comprising more than 200 species (McPherson, 2010). Numerous Drosera species are distributed worldwide across tropical to tundra regions, except for deserts and Antarctica. The largest number of species is concentrated in Australia and New Zealand but others can be found only in America, South Africa or Europe (Rivadavia et al., 2003). The leaves of Drosera plants have developed sticky traps that attract, trap and digest prey using the resulting nutrients to supplement what they can obtain from poor growing substrates (Rice, 2011).

The unique biology and carnivorous habit of Drosera spp. have gained the interest of horticulturists and made sundews economically important ornamentals (Barthlott et al., 2004). Besides their ornamental traits Drosera species are also valued for their medicinal properties (Kawiak et al., 2011) and are widely used in folk medicine. Extracts from these plants are included in herbal preparations used in the therapy of respiratory tract infections (Egan and van der Kooy, 2013). Therapeutic properties are thought to result from the presence of bioactive compounds which can be used in the production of pharmaceutical drugs (Banasiuk et al., 2012). The main secondary metabolites in Drosera plants are 1,4 naphthoquinones, among which the most abundant are plumbagin and 7-methyljuglone (ramentaceone). Besides these sundews synthesize several minor, but unique, naphthoquinones as well as a broad spectrum of flavonoids such as myricetin, quercetin (Devi et al., 2016; Braunberger et al., 2015; Krolicka et al., 2008).

Drosera rotundifolia has a prostrate growth 
habit with leaves in contact with the soil (Anthony, 1992) and is one of the most broadly distributed species, occurring throughout much of the Holarctic (Wolf et al., 2006). It is among the few species of carnivorous plants that can be found in Romania with a habitat made of acidic peat bogs in the mountains (Clapa et al., 2009). It has been prescribed as a diuretic, a laxative, and treatment for a variety of kidney, stomach, and liver problems (Wolf et al., 2006).

Drosera capensis is a small, erect perennial sundew native to the Cape region of South Africa (Pavlovič et al., 2014) and its plumbagin production has been reviewed by Egan and van der Kooy (2013). Extract from D. capensis leaves could be effective in fighting antibiotic-resistant Staphylococcus aureus strains (Krolicka et al., 2008).

The unfortunate side effect of the interest generated by sundews is overharvesting from natural sources. Together with a loss of their natural habitats this has led to their protection and inclusion in the European Red List of Threatened Plants (Kawiak et al., 2003). Another result has been the surge in research regarding the micropropagation and the use of in vitro-grown plants as alternative sources of biomass (Hook, 2001).

This experiment aimed to find the most suitable nutrient concentration and to study the effect of several plant growth regulators (kinetin, 6-benzyladenine, $\alpha$-naphthaleneacetic acid) for in vitro shoot development and rooting of $D$. rotundifolia and D. capensis.

\section{MATERIALS AND METHODS}

The experiments used plant material from established in vitro cultures of $D$. rotundifolia and D. capensis maintained on half-strength MS medium (Murashige and Skoog, 1962) without plant growth regulators. These cultures originated from seeds provided by the Cluj-Napoca Botanical Garden. Unless otherwise stated all reagents were acquired from Sigma-Aldrich, Germany.

The employed media were: full strength MS (fullMS) and MS with half-strength macronutrients, half-strength micronutrients and full vitamins (1/2MS). Both types of media were enriched with $30 \mathrm{~g} / \mathrm{l}$ sucrose, solidified with $5 \mathrm{~g} / \mathrm{l}$ phytagel and $\mathrm{pH}$ was adjusted to 5.4-5.5 before autoclaving at $121^{\circ} \mathrm{C}$ for $20 \mathrm{~min}$. After sterilization half-strength
MS was supplemented with kinetin $(0.5 \mathrm{mg} / \mathrm{l}, 2$ $\mathrm{mg} / \mathrm{l}, 5 \mathrm{mg} / \mathrm{l}$ ) or 6-benzyladenine (BA) (3 mg/l, 5 $\mathrm{mg} / \mathrm{l}$ ), with cytokinin concentrations being chosen based on other published studies. $D$. rotundifolia and $D$. capensis plantlets $(10-15 \mathrm{~mm}$ in length, 7-10 leaves) were selected from an established in vitro culture and transferred to $1 / 2 \mathrm{MS}$ without plant growth regulators $(1 / 2 \mathrm{MS} 0)$ or to $1 / 2 \mathrm{MS}$ containing one of the two cytokinins. Plants were kept for 8 weeks in the growing chamber at 20 $25^{\circ} \mathrm{C}$ under a $18 / 6 \mathrm{~h}$ light/dark regime provided by cool white fluorescent lamps with a light intensity of $40 \mu \mathrm{mol} / \mathrm{m}^{2} / \mathrm{s}$. Afterwards, rosette diameter, plant height, number of shoots, number of roots, root length, were measured and number of roots and shoots per explant was calculated. $D$. rotundifolia grows in horizontal rosettes which can be accurately defined by rosette diameter while in our experiment $D$. capensis formed stems which were better assessed by measuring plant height. Plants were placed in fullMS without plant growth regulators (fullMS0), $1 / 2 \mathrm{MS} 0$ or $1 / 2 \mathrm{MS}$ supplemented with $0.5 \mathrm{mg} / \mathrm{l} \alpha$-naphthaleneacetic acid ( $\alpha$-NAA) for another 8 weeks. At the end of this time the number of roots, and root length, number of shoots and flower stalks were assessed. These measurements were used to calculate number of roots, shoots and flower stalks per explant. Five plantlets per vessel were inoculated for each treatment and treatments were repeated 5 times. Data were analysed by the analysis of variance and differences were estimated using the Tuckey and $t$ tests at $p<0.05$. These were performed using GraphPad InStat version 3.05 for Windows 95 (GraphPad Software, San Diego California, USA).

\section{RESULTS AND DISCUSSIONS}

In $D$. rotundifolia kinetin and BA promoted significantly larger rosette diameter than medium without plant growth regulators, the best being $0.5 \mathrm{mg} / \mathrm{l}$ kinetin (Tab. 1.). The same treatment resulted in the largest number of shoots/explant while $3 \mathrm{mg} / \mathrm{l} \mathrm{BA}$ was second and no shoots were generated in $1 / 2 \mathrm{MS} 0$. The largest number of roots/explant was counted for $0.5 \mathrm{mg} / \mathrm{l}$ kinetin but their average length was smaller than that of roots grown in medium lacking plant growth regulators. None of the other treatments resulted in growth and explants died before the end of the 8 weeks.

This suggests that plants develop better in 
Tab. 1. Effect of cytokinins on growth and developmental characteristics of Drosera rotundifolia and Drosera capensis

\begin{tabular}{|c|c|c|c|c|c|}
\hline Treatment & $\begin{array}{c}\text { Drosera } \\
\text { rotundifolia }\end{array}$ & $\begin{array}{c}\text { Rosette } \\
\text { diameter }(\mathrm{cm})\end{array}$ & $\begin{array}{c}\text { Number of } \\
\text { roots/explant }\end{array}$ & $\begin{array}{l}\text { Root length } \\
(\mathrm{cm})\end{array}$ & $\begin{array}{c}\text { Number of } \\
\text { shoots/explant }\end{array}$ \\
\hline 1/2MS0 & & $1.73 \pm 0.071 \mathrm{a}$ & $2.01 \pm 0.06 \mathrm{a}$ & $2.40 \pm 0.08 a$ & $0.00 \pm 0.00$ \\
\hline $0.5 \mathrm{mg} / \mathrm{l}$ kinetin & & $3.61 \pm 0.101 b$ & $3.83 \pm 2.07 a$ & $1.30 \pm 0.63 a$ & $3.43 \pm 0.07 a$ \\
\hline 2 mg/l kinetin & & $0.00 \pm 0.00$ & $0.00 \pm 0.00$ & $0.00 \pm 0.00$ & $0.00 \pm 0.00$ \\
\hline $5 \mathrm{mg} / \mathrm{l}$ kinetin & & $0.00 \pm 0.00$ & $0.00 \pm 0.00$ & $0.00 \pm 0.00$ & $0.00 \pm 0.00$ \\
\hline $3 \mathrm{mg} / \mathrm{l}$ kinetin & & $3.21 \pm 0.043 c$ & $0.00 \pm 0.00$ & $0.00 \pm 0.00$ & $2.45 \pm 0.06 b$ \\
\hline $5 \mathrm{mg} / \mathrm{l} \mathrm{kinetin}$ & & $0.00 \pm 0.00$ & $0.00 \pm 0.00$ & $0.00 \pm 0.00$ & $0.00 \pm 0.00$ \\
\hline Treatment & $\begin{array}{l}\text { Drosera } \\
\text { capensis }\end{array}$ & $\begin{array}{c}\text { Plant height } \\
(\mathrm{mm})\end{array}$ & $\begin{array}{c}\text { Number of } \\
\text { roots/explant }\end{array}$ & $\begin{array}{l}\text { Root length } \\
(\mathrm{mm})\end{array}$ & $\begin{array}{c}\text { Number of } \\
\text { shoots/explant }\end{array}$ \\
\hline 1/2MS0 & & $2.81 \pm 0.41 \mathrm{a}$ & $2.22 \pm 0.40 \mathrm{a}$ & $2.92 \pm 0.17 \mathrm{a}$ & $6.67 \pm 0.84 a$ \\
\hline $0.5 \mathrm{mg} / \mathrm{l}$ kinetin & & $0.00 \pm 0.00$ & $0.00 \pm 0.00$ & $0.00 \pm 0.00$ & $0.00 \pm 0.00$ \\
\hline 2 mg/l kinetin & & $0.00 \pm 0.00$ & $0.00 \pm 0.00$ & $0.00 \pm 0.00$ & $0.00 \pm 0.00$ \\
\hline $5 \mathrm{mg} / \mathrm{l} \mathrm{kinetin}$ & & $0.00 \pm 0.00$ & $0.00 \pm 0.00$ & $0.00 \pm 0.00$ & $0.00 \pm 0.00$ \\
\hline $3 \mathrm{mg} / \mathrm{l} \mathrm{BA}$ & & $0.00 \pm 0.00$ & $0.00 \pm 0.00$ & $0.00 \pm 0.00$ & $0.00 \pm 0.00$ \\
\hline $5 \mathrm{mg} / \mathrm{l} \mathrm{BA}$ & & $0.00 \pm 0.00$ & $0.00 \pm 0.00$ & $0.00 \pm 0.00$ & $0.00 \pm 0.00$ \\
\hline
\end{tabular}

Note: Values expressed are mean \pm standard error of the mean (SEM). Different letters between means within the same column denote significant differences $(\mathrm{p}<0.05)$.

medium with reduced cytokinin concentration and that kinetin is better than BA. Our results are in contrast with those of Clapa et al. (2010) who found that $5 \mathrm{mg} / \mathrm{l}$ kinetin ensured a high proliferation rate in $D$. rotundifolia but are similar to those of Coelho (2009) who reported $0.1 \mathrm{mg} / \mathrm{l}$ kinetin in $1 / 4 \mathrm{MS}$ or $1 / 2 \mathrm{MS}$ as the best media for $D$. intermedia development. In the same species $0.1 \mathrm{mg} / \mathrm{l}$ zeatin provided the best results for shoot proliferation while kinetin and BA supressed it (Rejthar et al., 2014).

In our experiment $D$. capensis plants developed in MS0 but not in MS supplemented with growth regulators. After 8 weeks of culture the plants were small as suggested by rosette diameter for $D$. rotundifolia and plant height for D. capensis. High concentrations of plant growth regulators: $2 \mathrm{mg} / \mathrm{l}, 5 \mathrm{mg} / \mathrm{l}$ kinetin and $3 \mathrm{mg} / \mathrm{l}, 5 \mathrm{mg} / \mathrm{l} \mathrm{BA}$ did not promote plant development as shown by the growth characteristics. These plants were placed in 3 types of media for an additional 8 weeks to see if development could be improved by different nutrient concentrations or an auxin, namely $\alpha$-NAA. For $D$. rotundifolia plants more roots grew in $1 / 2 \mathrm{MS} 0$ than in any other medium (Tab. 2.).

They were significantly longer in the

Tab. 2. Effect of nutrient concentration and $\alpha$-NAA on growth and developmental characteristics of Drosera rotundifolia and Drosera capensis

\begin{tabular}{cccccc}
\hline Treatment & $\begin{array}{c}\text { Drosera } \\
\text { rotundifolia }\end{array}$ & $\begin{array}{c}\text { Number of } \\
\text { roots/explant }\end{array}$ & $\begin{array}{c}\text { Root length } \\
(\mathrm{cm})\end{array}$ & $\begin{array}{c}\text { Number of } \\
\text { shoots/explant }\end{array}$ & $\begin{array}{c}\text { Number of flower } \\
\text { stalks/explant }\end{array}$ \\
\hline fullMS0 & & $12.79 \pm 2.44 \mathrm{a}$ & $3.05 \pm 0.26 \mathrm{a}$ & $28.33 \pm 6.08 \mathrm{a}$ & $8.31 \pm 1.35 \mathrm{a}$ \\
$1 / 2 \mathrm{MS} 0$ & & $14.77 \pm 1.52 \mathrm{a}$ & $2.52 \pm 0.18 \mathrm{a}$ & $22.12 \pm 5.78 \mathrm{ab}$ & $4.88 \pm 1.28 \mathrm{ab}$ \\
$0.5 \mathrm{mg} / \mathrm{l} \alpha$-NAA & & $11.67 \pm 3.29 \mathrm{a}$ & $1.30 \pm 0.34 \mathrm{~b}$ & $4.97 \pm 1.72 \mathrm{~b}$ & $2.67 \pm 0.83 \mathrm{~b}$ \\
\hline \multirow{2}{*}{ Treatment } & Drosera & Number of & $\begin{array}{c}\text { Root length } \\
\text { (mm) }\end{array}$ & $\begin{array}{c}\text { Number of } \\
\text { shoots/explant }\end{array}$ & $\begin{array}{c}\text { Number of flower } \\
\text { stalks/explant }\end{array}$ \\
\hline fullMS0 & & $8.23 \pm 3.23 \mathrm{a}$ & $1.33 \pm 0.14 \mathrm{ab}$ & $9.20 \pm 3.51 \mathrm{a}$ & $0.10 \pm 0.10 \mathrm{a}$ \\
$1 / 2 \mathrm{MS0}$ & & $5.17 \pm 1.23 \mathrm{a}$ & $1.35 \pm 0.12 \mathrm{a}$ & $6.06 \pm 1.87 \mathrm{a}$ & $0.00 \pm 0.00$ \\
$0.5 \mathrm{mg} / \mathrm{l} \alpha$-NAA & & $4.28 \pm 1.24 \mathrm{a}$ & $0.74 \pm 0.21 \mathrm{~b}$ & $6.39 \pm 2.24 \mathrm{a}$ & $0.00 \pm 0.00$
\end{tabular}

Note: Values expressed are mean \pm standard error of the mean (SEM). Different letters between means within the same column denote significant differences $(\mathrm{p}<0.05)$. 
absence of plant growth regulators regardless of nutrient concentration. Media without plant growth regulators also supported the formation of significantly more shoots and flower stalks per explant. The presence of numerous flower stalks suggests that the plants can undergo a full life cycle in this type of medium even in the absence of $\mathrm{GA}_{3}$ which has been used to stimulate flowering in $D$. capillaris (Vásquez-Collantes et al., 2014). In D. capensis the best medium was fullMS0 which resulted in the development of the largest number of roots and shoots per explant. For the same species nutrient concentration had very little influence on root length but its decrease resulted in reduced numbers of roots and shoots per explant.

Poorer root development in $\alpha$-NAA supplemented MS is surprising given that this auxin is usually used for root induction. It is unexpected particularly given that various $\alpha$-NAA concentrations have been previously used for rooting experiments in Drosera species: $D$. cuneifolia (Kawiak et al., 2003), D. indica (Jayaram and Prasad, 2007) and D. spatulata (Perica, 1996), On the other hand Anthony (1992) reported that subcultured $D$. rotundifolia and $D$. capensis plantlets produced extensive root systems on 1/2MS without plant growth regulators but behaved poorly in media containing $0.02 \mathrm{mg} / \mathrm{l} \mathrm{BA}$ and 0.01 mg/l NAA. This suggests that $D$. rotundifolia and $D$. capensis do not need $\alpha$-NAA supplementation for successful rooting or that they need less than 0.5 $\mathrm{mg} / \mathrm{l}$. Our results contrast with those of Yanthan et al. (2017) who found that one-fourth strength MS supplemented with $4 \mathrm{mg} / \mathrm{l} \mathrm{BA}$ and $4 \mathrm{mg} / \mathrm{l}$ or fortified with $4 \mathrm{mg} / \mathrm{l}$ kinetin and $4 \mathrm{mg} / \mathrm{l} \mathrm{NAA}$ supported the growth of large numbers of shoots and roots.

The two species used in our study grew more vigorously and rooted better in media lacking plant growth regulators. This is comparable to the work of Anthony (1992) who reported that using $0.02 \mathrm{mg} / \mathrm{l} \mathrm{BA}$ and $0.01 \mathrm{mg} / \mathrm{l} \mathrm{NAA}$ in $1 / 2 \mathrm{MS}$ or $1 / 4$ MS resulted in large numbers of $D$. rotundifolia and D. capensis plantlets. Similar results were obtained by Jayaram and Prasad (2007) for D. indica with low concentrations of cytokinins (zeatin and kinetin) being the best while high concentrations resulted in retardation of shoot growth.

\section{CONCLUSION}

In the current experiment the most suitable medium for $D$. rotundifolia shoot production was half-strength MS supplemented with a low kinetin concentration $(0.5 \mathrm{mg} / \mathrm{l})$ while rooting was best in medium free of kinetin or $\alpha$-NAA. In $D$. capensis half-strength medium without plant growth regulators was the best for shoot development and rooting was highest in full strength MS. Because D. rotundifolia and D. capensis are prized for their ornamental and medicinal properties this optimized protocol can be used for large scale propagation for commercial and conservation purposes.

\section{REFERENCES}

1. Anthony JL (1992). In vitro propagation of Drosera spp. HortScience 27(7):850.

2. Banasiuk R, Kawiak A, Krolicka A (2012). In vitro cultures of carnivorous plants from the Drosera and Dionaea genus for the production of biologically active secondary metabolites. J Biotechnol Comput Biol Bionanotechnol 93(2):87-96.

3. Barthlott W, Porembski S, Seine R, Theisen I (2004). The curious world of carnivorous plants: A comprehensive guide to their biology and cultivation. Portland: Timber Press.

4. Braunberger C, Zehl M, Conrad J, Wawrosch C, Strohbach J, Beifuss U, Krenn L (2015). Flavonoids as chemotaxonomic markers in the genus Drosera. Phytochemistry 118:74-82.

5. Clapa D, Fira A, Pacurar I (2009). In vitro multiplication, conservation and ex vitro acclimation of Drosera rotundifolia. Bulletin UASVM Horticulture 66(1):34-39.

6. Clapa D, Fira A, Pacurar I, Sotropa A (2010). Possibilities for the propagation and re-population of peat bogs with carnivorous species. Agricultura-Știinţă și practică 3-4 (75-76):21-26.

7. Coelho N (2009). In vitro propagation of insectivorous plants for phytochemical purposes. Master Thesis, Universidade do Algarve.

8. Devi SP, Kumaria S, Rao SR, Tandon P (2016). Carnivorous plants as a source of potent bioactive compound: naphthoquinones. Tropical Plant Biol 9(4):267-279.

9. Egan PA, van der Kooy F (2013). Phytochemistry of the carnivorous sundew genus Drosera (Droseraceae) future perspectives and ethnopharmacological relevance. Chem Biodivers 10: 1774-1790.

10. Jayaram K, Prasad MNV (2007). Rapid in vitro multiplication of Drosera indica L.: a vulnerable, medicinally important insectivorous plant. Plant Biotechnol Rep 1:79-84.

11. Hook IL (2001). Naphthoquinone content of in vitro cultured plants and suspension of Dionaea muscipula and Drosera species. Plant Cell Tiss Organ Cult 67:281-285.

12. JayaramK, Prasad MNV (2007). Rapid in vitro multiplication of Drosera indica L.: a vulnerable, medicinally important insectivorous plant. Plant Biotechnol Rep 1:79-84. 
13. Kawiak A, Królicka A, Lojkowska E (2011). In vitro cultures of Drosera aliciae as a source of a cytotoxic naphthoquinone: ramentaceone. Biotechnol Lett 33(11):2309-2316.

14. Kawiak A, Królicka A, Lojkowska E (2003). Direct regeneration of Drosera from leaf explants and shoot tips. Plant Cell Tissue and Organ Cult 75:175-178.

15. Krolicka A, Szpitter A, Gilgenast E, Romanik G, Kamiński M, Lojkowska E (2008). Stimulation of antibacterial naphthoquinones and flavonoids accumulation in carnivorous plants grown in vitro by addition of elicitors. Enzyme Microbial Technol 42:216-221.

16. McPherson S (2010). Carnivorous plants and their habitats. vol 2, Redfern Natural History, Poole.

17. Murashige T, Skoog F (1962). A revised medium for rapid growth and bioassays with tobacco tissue cultures. Physiol Plant 15:474-497.

18. Pavlovič A, Krausko M, Libiaková M, Adamec L (2014). Feeding on prey increases photosynthetic efficiency in the carnivorous sundew Drosera capensis. Ann Bot 113(1):6978.

19. Perica MC (1996). In vitro growth and regeneration of Drosera spatulata Labill. on various media. HortScience: 31(6):1033-1034
20. Rejthar J, Viehmannova I, Cepkova PH, Fernández E, Milella L (2014). In vitro propagation of Drosera intermedia as influenced by cytokinins, $\mathrm{pH}$, sucrose, and nutrient concentration. Emir J Food Agric 26(6):558-564.

21. Rice BA (2011). Reversing the roles of predator and prey. In J. Seckbach \& Z. Dubinsk (Eds.), Cellular origin, life in extreme habitats and astrobiology. All flesh is grass: Plant-animal interrelationships vol 16, (pp. 491-518) Berlin: Springer.

22. Rivadavia F, Kondo K, Kato M, Hasebe M (2003) Phylogeny of the sundews, Drosera (Droseraceae) based on chloroplast rbcL and nuclear 18S ribosomal DNA sequences. Am J Bot 90:123-130.

23. Vasquez-Collantes SG, Rojas-Idrogo C, Delgado-Paredes GE (2014). In vitro flowering and plantlets elongation in "sundew" Drosera capillaris. International Journal of Plant, Animal and Environmental Sciences 4(3): 508-517.

24. Wolf E, Gage E, Cooper DJ (2006). Drosera rotundifolia L. (roundleaf sundew): a technical conservation assessment. USDA Forest Service, Rocky Mountain Region. Available: http://www.fs.fed.us/r2/projects/scp/assessments / droserarotundifolia.pdf Accessed 22.08.2017

25. Yanthan JS, Kehie M, Kumaria S, Tandon P (2017). In vitro regeneration of Drosera burmannii Vahl.: a carnivorous plant of north-east India. 3 Biotech 7(2):124. 